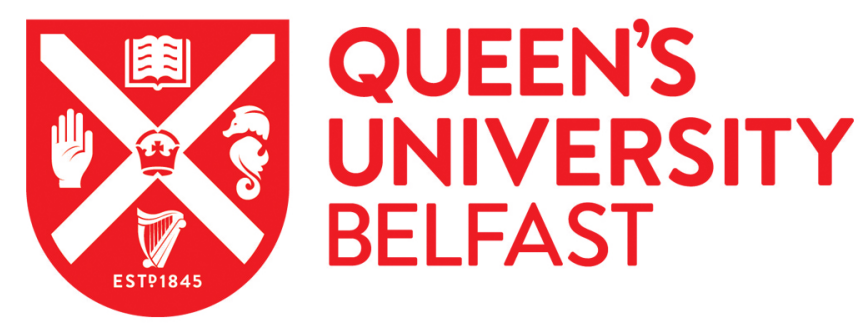

\title{
Determination of the persistence of dimetridazole, metronidazole and ronidazole residues in black tiger shrimp (Penaeus monodon) tissue and stability during cooking
}

Gadaj, A., Cooper, K. M., Karoonuthaisiri, N., Furey, A., \& Danaher, M. (2015). Determination of the persistence of dimetridazole, metronidazole and ronidazole residues in black tiger shrimp (Penaeus monodon) tissue and stability during cooking. Food Additives and Contaminants: Part A, 32(2), 180-193.

https://doi.org/10.1080/19440049.2014.983997

\section{Published in:}

Food Additives and Contaminants: Part A

\section{Document Version:}

Peer reviewed version

Queen's University Belfast - Research Portal:

Link to publication record in Queen's University Belfast Research Portal

\section{Publisher rights}

This is an Accepted Manuscript of an article published by Taylor \& Francis in Food Additives \& Contaminants: Part A, volume 32, issue 2, 2015, available online: http://wwww.tandfonline.com/10.1080/19440049.2014.983997.

\section{General rights}

Copyright for the publications made accessible via the Queen's University Belfast Research Portal is retained by the author(s) and / or other copyright owners and it is a condition of accessing these publications that users recognise and abide by the legal requirements associated with these rights.

Take down policy

The Research Portal is Queen's institutional repository that provides access to Queen's research output. Every effort has been made to ensure that content in the Research Portal does not infringe any person's rights, or applicable UK laws. If you discover content in the

Research Portal that you believe breaches copyright or violates any law, please contact openaccess@qub.ac.uk. 
This article was downloaded by: [The Library at Queen's University]

On: 15 December 2014, At: 04:15

Publisher: Taylor \& Francis

Informa Ltd Registered in England and Wales Registered Number: 1072954 Registered office: Mortimer House, 37-41 Mortimer Street, London W1T 3J H, UK

Food Additives

Contaminants

CrossMark

Click for updates

\section{Food Additives \& Contaminants: Part A}

Publication details, including instructions for authors and subscription information: http:// www. tandfonline.com/loi/tfac20

\section{Determination of the persistence of dimetridazole, metronidazole and ronidazole residues in black tiger shrimp (Penaeus monodon) tissue and stability during cooking}

\author{
Anna Gadaj ${ }^{a b}$, Kevin M. Cooper ${ }^{c}$, Nitsara Karoonuthaisiri ${ }^{d}$, Ambrose Furey ${ }^{b}$ \& Martin \\ Danaher $^{a}$ \\ ${ }^{a}$ Food Safety Department, Teagasc Food Research Centre, Dublin 15, Ireland \\ b Team Elucidate, Department of Chemistry, Cork Institute of Technology, Cork, Ireland \\ c Institute for Global Food Security, Queen's University Belfast, Belfast, UK \\ d Microarray Laboratory, National Centre for Genetic Engineering and Biotechnology, \\ Pathumthani, Thailand \\ Accepted author version posted online: 05 Nov 2014.
}

To cite this article: Anna Gadaj, Kevin M. Cooper, Nitsara Karoonuthaisiri, Ambrose Furey \& Martin Danaher (2014): Determination of the persistence of dimetridazole, metronidazole and ronidazole residues in black tiger shrimp (Penaeus monodon) tissue and stability during cooking, Food Additives \& Contaminants: Part A, D0I: 10.1080/ 19440049.2014.983997

To link to this article: http:// dx. doi.org/ 10.1080/ 19440049.2014.983997

Disclaimer: This is a version of an unedited manuscript that has been accepted for publication. As a service to authors and researchers we are providing this version of the accepted manuscript (AM). Copyediting, typesetting, and review of the resulting proof will be undertaken on this manuscript before final publication of the Version of Record (VoR). During production and pre-press, errors may be discovered which could affect the content, and all legal disclaimers that apply to the journal relate to this version also.

\section{PLEASE SCROLL DOWN FOR ARTICLE}

Taylor \& Francis makes every effort to ensure the accuracy of all the information (the "Content") contained in the publications on our platform. However, Taylor \& Francis, our agents, and our licensors make no representations or warranties whatsoever as to the accuracy, completeness, or suitability for any purpose of the Content. Any opinions and views expressed in this publication are the opinions and views of the authors, and are not the views of or endorsed by Taylor \& Francis. The accuracy of the Content should not be relied upon and should be independently verified with primary sources of information. Taylor and Francis shall not be liable for any losses, actions, claims, proceedings, demands, costs, expenses, damages, and other liabilities whatsoever or howsoever caused arising directly or indirectly in connection with, in relation to or arising out of the use of the Content.

This article may be used for research, teaching, and private study purposes. Any substantial or systematic reproduction, redistribution, reselling, loan, sub-licensing, systematic supply, or distribution in any form to anyone is expressly forbidden. Terms \& Conditions of access and use can be found at http:// www.tandfonline.com/page/terms-and-conditions 
Publisher: Taylor \& Francis

Journal: Food Additives \& Contaminants: Part A

DOI: $10.1080 / 19440049.2014 .983997$

\title{
Determination of the persistence of dimetridazole, metronidazole and ronidazole residues in black tiger shrimp (Penaeus monodon) tissue and stability during cooking
}

Anna Gadaj ${ }^{\mathrm{a}, \mathrm{b}}$, Kevin M. Cooper ${ }^{\mathrm{c}}$, Nitsara Karoonuthaisiri ${ }^{\mathrm{d}}$, Ambrose Furey ${ }^{\mathrm{b}}$ and Martin Danaher $^{\mathrm{a} *}$

${ }^{\mathrm{a}}$ Food Safety Department, Teagasc Food Research Centre, Ashtown, Dublin 15, Ireland. ${ }^{\mathrm{b}}$ Team Elucidate, Department of Chemistry, Cork Institute of Technology, Bishopstown, Cork, Ireland. 'Institute for Global Food Security, Queen's University Belfast, Belfast, UK. ${ }^{\mathrm{d}}$ Microarray Laboratory, National Centre for Genetic Engineering and Biotechnology, Pathumthani, Thailand

*Corresponding author: martin.danaher@teagasc.ie

\begin{abstract}
The depletion of three banned nitroimidazole drugs (dimetridazole (DMZ), metronidazole (MNZ) and ronidazole (RNZ)) was investigated in black tiger shrimp (Penaeus monodon) following in-water medication. The highest concentrations of residues were measured immediately after the $24 \mathrm{~h}$ immersion (day 0). At this time, MNZ and MNZ-OH residues were measured in shrimp tissue samples at concentrations ranging from $361-4189$ and 0.28
\end{abstract}


- $6.6 \mu \mathrm{g} \mathrm{kg}^{-1}$, respectively. DMZ and its metabolites HMMNI ranged in concentration between $31509-37780$ and $15.0-31.9 \mu \mathrm{g} \mathrm{kg}$, respectively. RNZ and HMMNI concentrations ranged 14530 - 24206 and $25.0-55 \mu \mathrm{g} \mathrm{kg}{ }^{-1}$, respectively. MNZ, DMZ and RNZ were the more persistent marker residues and can be detected for at least eight days post-treatment. MNZ-OH was only detectable on day 0 following treatment with MNZ. HMMNI residues were only detectable up to day $1\left(0.97-3.2 \mu \mathrm{g} \mathrm{kg}^{-1}\right)$ or $2\left(1.2-4.5 \mu \mathrm{g} \mathrm{kg}^{-1}\right)$ following DMZ and RNZ treatment, respectively. The parent drugs, MNZ, DMZ and RNZ were still measureable on day 8 at $0.12-1.00,40.5-55$ and $8.8-18.7 \mu \mathrm{g} \mathrm{kg}^{-1}$, respectively. The study also investigated the stability of nitroimidazole residues under various cooking procedures (frying, grilling, boiling and boiling followed by microwaving). The experiments were carried out in shrimp muscle tissue containing both high and low concentrations of these residues. Different cooking procedures showed the impact on nitroimidazole residue concentration in shrimp tissue - their concentration depleted significantly, but partially, by boiling and/or microwaving but the compounds were largely resistant to conventional grilling or frying. Cooking cannot therefore be considered as a safeguard against harmful nitroimidazole residues in shrimp.

Keywords: nitroimidazole residues, dimetridazole, HMMNI, metronidazole, metronidazole$\mathrm{OH}$, ronidazole, shrimp, persistence, stability, cooking, UHPLC-MS/MS

\section{Introduction}

Shrimp farming has increased significantly over the last couple of decades and by 2007 exceeded the global catch of all marine shrimps (Valderrama and Anderson 2011). In 2010 , the value of shrimp production accounted for approximately $15 \%$ of the total value of internationally traded fishery products which made shrimp the largest single commodity in 
terms of value (Anon. 2012). However, shrimp farming has faced serious disease outbreaks from viral, bacterial and parasitic infections causing significant economic loss (Chou et al. 1995). For instance, diseases outbreaks have resulted in the collapse of the penaeid shrimp aquaculture industry in Taiwan in the late 1980s (Kautsky et al. 2000), caused a \$750 million loss in 1993 in China and \$210 million in 1995-1996 in India (Primavera 1998). Indeed, disease outbreaks have resulted in the dramatic decline in the production during 1994-2004.

The protozoan parasites in shrimp that can cause diseases including several groups such as Microspora, Haplospora and Gregarina (Johnson 1995; Lightner 1996). For instance, microsporidians can cause a cotton shrimp disease (Hose et al. 1984) whereas the Haplospora group destroy the tissues of the shrimp digestive gland (Johnson 1995). Gregarines are a common intestinal parasite for shrimp. Some parasites in this group, such as Nematopsis penaeus, have been reported to cause severe damage in the gut mucosal epithelium of shrimp and associated with mortality and lesions (Fajer-Ávila et al. 2005).

In contrast to terrestrial food producing animals, few veterinary medicines are licensed for treating aquaculture species (Bishop 2005). Consequently, there is a concern about the illegal application of veterinary drugs to prevent or to treat infectious diseases in aquaculture. Several studies were performed to evaluate effectiveness of antibiotics in different farmed aquaculture species (Clopton and Smith 2002; Smith and Clopton 2003; Fajer-Ávila et al. 2005) as well as depletion of these antibiotics (Corliss 1979; Poapolathep et al. 2008). The consumption of shrimps containing banned substances is of continuing concern and there is an ongoing need for knowledge on the persistence of residues in shrimp tissue for risk assessment purposes.

Nitroimidazoles are known to be effective in the treatment of parasitic infections in aquaculture species, but currently metronidazole (MNZ) is licensed only for ornamental fish (Tojo and Santamarina 1998a; Tojo and Santamarina 1998b; Bishop 2005). Nitroimidazoles 
and their corresponding hydroxy metabolites are suspected to be carcinogenic and mutagenic to humans (Raether and Hänel 2003). As a consequence the EU banned the use of nitroimidazole drugs (dimetridazole (DMZ), metronidazole (MNZ) and ronidazole (RNZ)) in food-producing animals or in products intended for human consumption under Regulation 2377/90 (Anon. 1990), replaced by 470/2009 (Anon. 1990) and 37/2010 (Anon. 2010). DMZ, MNZ and RNZ are classified as prohibited pharmacologically active substances for which no MRL can be established as they constitute a hazard to the health of the consumer at whatever limit (Anon. 1990). For this reason, confirmation of the presence of dimetridazole, metronidazole and ronidazole residues or their corresponding hydroxy metabolites (namely HMMNI and metronidazole-OH) at any concentration must be considered as a violation of the EU regulation. In order to protect a public health and harmonise trade, DMZ, MNZ, RNZ and their hydroxy metabolites have each been assigned a recommended concentration of $3 \mu \mathrm{g}$ $\mathrm{kg}^{-1}$, for the performance of analytical methods, by the EU Reference Laboratory in Berlin (Anon. 2007).

A number of animal studies with different species (laying hens, turkeys and pigs) employing different nitroimidazole drugs (dimetridazole, ipronidazole, metronidazole and ronidazole) have been carried out in the past (Polzer et al. 2004). However, there are no references in the peer-reviewed literature to the depletion studies of nitroimidazoles in farmed aquaculture species. Moreover, most information regarding veterinary drug residues in food is related to their concentrations in raw tissue, but most food of animal origin including aquaculture is consumed after cooking or processing. Therefore, knowledge of the impact of cooking on veterinary drug residues is important for more accurate dietary exposure assessment. A review of the peer reviewed literature has shown that relatively few studies on the effect of cooking on residues have been reported (Rose et al. 1999; Cooper and Kennedy 2007; Mitrowska et al. 2007; Cooper et al. 2011). Furthermore, little is known about the 
stability of nitroimidazole residues in food under conventional cooking conditions. To date, the assessment of their stability in food has been limited to the effects of various cooking procedures including boiling, frying and microwaving, on dimetridazole, ronidazole and their metabolite, namely HMMNI, in egg and chicken muscle (Rose et al. 1999).

The objective of this study was to evaluate the elimination of dimetridazole, metronidazole and ronidazole residues in shrimp tissue following an in-water treatment and to determine the stability of these residues under various cooking procedures (frying, grilling, boiling and boiling followed by microwaving).

\section{Materials and methods}

\section{Materials and reagents}

All chemicals used in this research were analytical grade or better. Dimetridazole (DMZ), metronidazole (MNZ) and ronidazole (RNZ) were purchased from Sigma-Aldrich (Dublin, Ireland). HMMNI, metronidazole-OH (MNZ-OH), dimetridazole-d $\mathrm{d}_{3} \quad\left(\mathrm{DMZ}^{-} \mathrm{D}_{3}\right)$, HMMNI- $\mathrm{d}_{3}$, metronidazole-13C $2,15 \mathrm{~N}_{2}\left(\mathrm{MNZ}-13 \mathrm{C}_{2}, 15 \mathrm{~N}_{2}\right)$, metronidazole-OH- $\mathrm{d}_{2}(\mathrm{MNZ}-\mathrm{OH}-$ $\left.\mathrm{D}_{2}\right)$ and ronidazole- $\mathrm{D}_{3}\left(\mathrm{RNZ}-\mathrm{D}_{3}\right)$ were purchased from Witega (Berlin, Germany). All standards and internal standards stock solutions were prepared at a concentration of $1 \mathrm{mg} \mathrm{mL}^{-}$ ${ }^{1}$ in $\mathrm{MeOH}$ and $\mathrm{MeOH}-\mathrm{D}$, respectively.

Two complementary analytical methods covering the range $0.1-20 \mu \mathrm{g} \mathrm{kg}^{-1}$ (low residue method) and $20-10000 \mu \mathrm{g} \mathrm{kg}^{-1}$ (high residue method) were used in this study. A low residue method was reported previously (Gadaj et al. 2014), whereas an additional high residue procedure was developed and validated for the current study since the concentration of nitroimidazole residues detected in treated shrimp tissues at certain time points (day 0 (MNZ), day $0-8(\mathrm{DMZ})$ and day $0-4(\mathrm{RNZ}))$ exceeded the range of the initial method used. Consequently, two different working standards mixes were required for calibrations and 
controls. A high mixed calibration range was prepared at concentrations of $0.2($ std 1$), 0.5$ $(\operatorname{std} 2), 1(\operatorname{std} 3), 2.5(\operatorname{std} 4), 5(\operatorname{std} 5), 10(\operatorname{std} 6), 25(\operatorname{std} 7), 50(\operatorname{std} 8)$ and $100(\operatorname{std} 9) \mu \mathrm{g} \mathrm{mL} L^{-1}$ in $\mathrm{MeOH}$, by serial dilution of the stock solutions. The preparation of standards for a low calibration range is described elsewhere (Gadaj et al. 2014). An intermediate and a working internal standard mix solution were prepared at 100 and $5 \mu \mathrm{g} \mathrm{mL} \mathrm{L}^{-1}$ in $\mathrm{MeOH}-\mathrm{D}$, respectively. All standards and internal standards sock solutions, and intermediate mix solutions were found to be stable for at least one year when stored at $-20{ }^{\circ} \mathrm{C}$. Working calibration standard and a working internal standard mix solutions were found to be stable for at least three months when stored at $-20^{\circ} \mathrm{C}$.

\section{Analysis of nitroimidazole residues in test samples}

A finely chopped portion of each shrimp sample $1 \mathrm{~g} \pm 0.01 \mathrm{~g}$ was weighed into a 50 $\mathrm{mL}$ polypropylene tube. Samples were fortified with $50 \mu \mathrm{L}$ of a $5 \mu \mathrm{g} \mathrm{mL} \mathrm{m}^{-1}$ internal standard mix solution and left to stand for $15 \mathrm{~min}$. A $12 \mathrm{~mL}$ volume of $\mathrm{MeCN}$ was added into each tube. The tube contents were homogenised using an Ultra-Turrax probe blender for $30 \mathrm{~s}$ and 9 $\mathrm{mL}$ of $\mathrm{H}_{2} \mathrm{O}$ was subsequently added. After vortexing for $60 \mathrm{~s}, 1 \mathrm{~g}$ of $\mathrm{NaCl}$ and $4 \mathrm{~g}$ of $\mathrm{MgSO}_{4}$ was added to tubes, which were then shaken vigorously by hand for a minimum of $60 \mathrm{~s}$. Samples were centrifuged at $3500 \mathrm{rpm}(2842 \times g)$ for $12 \mathrm{~min}$ at $4{ }^{\circ} \mathrm{C} .1 \mathrm{~mL}$ of the supernatants were transferred to clean empty $5 \mathrm{~mL}$ glass tubes. Following the addition of $1 \mathrm{~mL}$ of $\mathrm{H}_{2} \mathrm{O}$, samples were vortexed for $60 \mathrm{~s}$. Extracts were filtered through $0.2 \mu \mathrm{m}$ PTFE $13 \mathrm{~mm}$ MillexFG syringe filters (Millipore, Cork, Ireland) and $2 \mu \mathrm{L}$ were injected onto the UHPLC-MS/MS system. The UHPLC-MS/MS conditions are described in detail elsewhere (Gadaj et al. 2014).

\section{Preparation of extracted matrix calibrants and recovery control checks}

Extracted matrix calibrants for the high residue method were prepared by fortifying negative shrimp samples $(1 \mathrm{~g} \pm 0.01 \mathrm{~g})$ prior to extraction with $100 \mu \mathrm{L}$ of each calibration standard solutions (standards 1 to 9 ) to give curves in the range $20-10000 \mu \mathrm{gg}^{-1}$. An 
additional four blank samples (recovery controls) were spiked after extraction to monitor for loss of analytes during extraction. Briefly, $6 \mathrm{~mL}$ of the supernatants were transferred to clean empty $15 \mathrm{~mL}$ polypropylene tubes and two tubes were spiked with $50 \mu \mathrm{L}$ of std $2\left(0.5 \mu \mathrm{g} \mathrm{mL}^{-1}\right)$ and two with $50 \mu \mathrm{L}$ of std $8\left(50 \mu \mathrm{g} \mathrm{mL} \mathrm{m}^{-1}\right)$. Samples were vortexed for $60 \mathrm{~s}$ and $1 \mathrm{~mL}$ of the extracts were transferred to clean empty $5 \mathrm{~mL}$ glass tubes. The preparation of extracted matrix calibrants and controls checks for the low residue method is described elsewhere (Gadaj et al. 2014)

\section{Method validation}

A low residue method validation was reported previously (Gadaj et al. 2014). Briefly, the method was validated according to the EU Commission Decision 2002/657/EC criteria and the following performance studies were carried out: selectivity, specificity, linearity of calibration curve, working range of the method, within laboratory repeatability (WLr), within laboratory reproducibility (WLR), accuracy, precision, decision limit (CC $\alpha$ ), detection capability $(\mathrm{CC} \beta)$, matrix effects, absolute recovery and stability. Validation was carried out at

\section{$1.5,3.0$ and $4.5 \mu \mathrm{g} \mathrm{kg}^{-1}$.}

Accuracy and precision of the method ranged from 96 to $103 \%$ and 1.6 to $14.0 \%$, respectively. The $\mathrm{CC} \alpha$ values for all nitroimidazoles and their corresponding hydroxy metabolites were below the recommended concentration of $3 \mu \mathrm{g} \mathrm{kg}^{-1}$, ranging $0.07-1.0 \mu \mathrm{g}$ $\mathrm{kg}^{-1}$ depending on the analyte.

In the case of a high residue method, the following analytical method performance parameters were investigated: linearity of calibration curve, working range of the method, intra- and inter-assay repeatability, accuracy, precision and absolute recovery. Both intra- and inter-assay repeatability studies were carried out by the same analyst. In total six runs were executed for the validation study. Five portions coming from the same negative control test material were used for the establishment of intra-assay repeatability, whereas two portions 
were used for the establishment of inter-assay repeatability, and the method was repeated on five separate days. The validation study was carried out by fortifying shrimp tissue samples at 40, 500 and $5000 \mu \mathrm{g} \mathrm{kg}^{-1}$.

\section{Shrimp experimental treatments and sampling}

All shrimp treatment studies were carried out at the Shrimp Biotechnology Business Unit (SBBU), Thailand. Black tiger shrimps (Penaeus monodon) were obtained from a farm in the Chachoengsao province. Upon arrival, the experimental shrimps were acclimatised in a $2000 \mathrm{~L}$ tank and reared with commercial feed until they reached a weight of $20-25 \mathrm{~g}$. The shrimp were fed four times daily at a $2 \%$ rate of total body weight.

A total of four $390 \mathrm{~L}$ tanks per drug were supplied with dimetridazole, metronidazole and ronidazole, respectively, at a concentration of $50 \mathrm{mg} \mathrm{L}^{-1}$ (volume of $353 \mathrm{~L}$ ) and a further two tanks with non-medicated static water system. The dose aimed in this bath treatment study was a therapeutic dose as recommended for metronidazole by the Veterinary Formulary (Bishop 2005). Aquaria conditions were maintained as the following: $\mathrm{pH} 7.5-8.5$, dissolved oxygen $>5 \mathrm{mg} \mathrm{L}^{-1}$, temperature $27-30^{\circ} \mathrm{C}$, salinity $15 \mathrm{~g} \mathrm{~L}^{-1}$, ammonia-nitrogen $<0.03 \mathrm{mg} \mathrm{N}$ $\mathrm{L}^{-1}$, nitrite-nitrogen $<1 \mathrm{mg} \mathrm{N} \mathrm{L}^{-1}$ and alkalinity $80-150 \mathrm{mg} \mathrm{CaCO}_{3} \mathrm{~L}^{-1}$. Thirty five shrimp were immersed for $24 \mathrm{~h}$ in each tank containing a nitroimidazole drug.

After the immersion, shrimps were transferred to normal sea water for eight days and collected at specified intervals: immediately (d0), day 1 (d1), day $2(\mathrm{~d} 2)$, day $4(\mathrm{~d} 4)$ and day 8 (d8). At each sampling time, six shrimp per tank (both medicated and non-medicated) were collected, rinsed with normal sea water, and stored in bags at $-20{ }^{\circ} \mathrm{C}$ prior to delivery in dry ice. The untreated shrimps were taken from original stock prior to the treatment to be used as a blank tissue. Upon arrival to Teagasc, shrimps were peeled and deveined manually. Shrimps were stored individually in $50 \mathrm{~mL}$ polypropylene tubes at $-70{ }^{\circ} \mathrm{C}$ until assayed, whereas the 
shrimps taken from original stock prior to the treatment were homogenised using a mechanical blender and stored in a bag at $-70^{\circ} \mathrm{C}$.

\section{Cooking of the incurred shrimp tissue}

\section{Methodology}

Dimetridazole, metronidazole and ronidazole-treated shrimps from two withdrawal time points ( $\mathrm{d} 0$ and $\mathrm{d} 8(\mathrm{DMZ}), \mathrm{d} 0$ and $\mathrm{d} 1(\mathrm{MNZ})$, and $\mathrm{d} 1$ and $\mathrm{d} 8(\mathrm{RNZ}))$ were selected $(n=$ 12 per time point). To mimic domestic cooking practices, individual intact shrimps $(4.60-$ $11.82 \mathrm{~g}$ ) were subjected to one of the following cooking procedures: frying (shallow), grilling (broiling), boiling and boiling followed by microwaving (to mimic preparation of supermarket ready-meals), and were analysed both raw and cooked using an UHPLC-MS/MS method within a single analysis. To minimise variable changes in weight due to water loss during sample freeze-thawing, the $2 \mathrm{~g}$ aliquots of raw tissue were weighed out at the same time as the aliquots of cooked shrimp. Samples were then refrozen at $-70{ }^{\circ} \mathrm{C}$ until assayed. Six replicate shrimps were tested for each of four cooking procedures. Negative controls were included to prove dimetridazole, metronidazole and ronidazole residues did not form during cooking. Negative controls, namely, two raw peeled king prawns purchased from a local supermarket were included for each cooking method, tested before and after cooking.

\section{Boiling}

Each of the pre-weighed shrimps was placed in an open $35 \mathrm{~mL}$ glass tube containing $15 \mathrm{~mL}$ of water sitting in a pot of boiling water on a domestic ceramic hob. Hob heat was reduced and the shrimps were allowed to simmer for $5 \mathrm{~min}$. After $5 \mathrm{~min}$, water in the tubes was decanted to clean polypropylene containers and allowed to cool to room temperature before measuring the total volume of water recovered. The cooked shrimps were placed immediately on tissue paper at $4{ }^{\circ} \mathrm{C}$ to halt the cooking process and remove excess water. After 30 min the cooked shrimps were weighed. 


\section{Boiling followed by microwaving}

Pre-weighed shrimps were boiled as described above including collection of water. After 30 min cooling at $4{ }^{\circ} \mathrm{C}$, the boiled shrimp was placed in a microwavable container covered with cling film and microwaved on full power ( $800 \mathrm{~W}$ oven) for $4 \mathrm{~min}$. Cooked shrimps were again cooled for $30 \mathrm{~min}$ at $4{ }^{\circ} \mathrm{C}$ on tissue paper and reweighed.

\section{Grilling}

Pre-weighed shrimps were brushed lightly with a minimal amount of sunflower oil to prevent burning and placed on a rack under a pre-heated domestic grill (high temperature) and grilled for 2 min each side, turning once (this standardised time may be adjusted depending on average size of the shrimps and observed time to cook completely). After cooking, excess oil was removed gently with tissue paper and shrimps were cooled for 30 min at $4{ }^{\circ} \mathrm{C}$ on tissue paper to halt the cooking process and reweighed.

\section{Frying}

Pre-weighed shrimps were placed in a pre-heated hot frying pan containing a minimal amount of sunflower oil to prevent burning. Shrimps were fried for $1.5 \mathrm{~min}$ on each side, turning once. After cooking, shrimps were cooled for $30 \mathrm{~min}$ at $4{ }^{\circ} \mathrm{C}$ and re-weighed.

\section{Results and discussion}

\section{Analytical methodology}

Several analytical methods have been reported for nitroimidazole residue analysis in different food matrices based on LC-MS/MS detection and they were found to be capable of the detection of target analytes in the low $\mu \mathrm{g} \mathrm{kg}^{-1}$ region, below the recommended concentration (Mottier et al. 2006; Peters et al. 2009; Smith et al. 2009; Mahugo-Santana et al. 2010; Mitrowska et al. 2010; Kaufmann et al. 2011; Gadaj et al. 2014). 
Shrimp samples from the immersion treatment experiment were initially analysed using the method that was previously developed by Gadaj et al. (2014) for the analysis of nitroimidazole residues in aquaculture tissue in the range of $0.1-20 \mu \mathrm{g} \mathrm{kg}^{-1}$. The analysis of shrimp tissue samples that were collected immediately (d0) after medication with MNZ, and day $0-8$ and $0-4$ after medications with $\mathrm{DMZ}$ and $\mathrm{RNZ}$, respectively, gave the concentration of the parent drug exceeding the range of the analytical method used. Therefore, a new method for the analysis of high residue samples, covering the range $20 \diamond 10000 \mu \mathrm{gg}^{-1}$ was developed and validated.

The linearity of the method was evaluated over the range $20-10000 \mu \mathrm{g} \mathrm{kg}^{-1}$ during validation studies. The linearity of the curves (measured as $R^{2}$ ) was satisfactory and greater than 0.99 . Shrimp samples were fortified at levels of 40,500 and $5000 \mu \mathrm{g} \mathrm{kg}^{-1}$. The results of the validation study collected in Table S2, supplementary data, show that the accuracy and precision were in the ranges of $95-114 \%$ and $1.0-12.4 \%$, respectively. Mean recoveries for nitroimidazole drug residues and their hydroxy metabolites were calculated by comparing the concentrations in fortified samples with concentrations in control samples spiked postextraction to be $91 \pm 5.9 \%$ (DMZ), $88 \pm 6.1 \%$ (HMMNI) and $90 \pm 4.1 \%(\mathrm{MNZ}), 84 \pm 8.5 \%$ $(\mathrm{MNZ}-\mathrm{OH})$ and $93 \pm 7.1 \%$ (RNZ). Recovery was based on data collected from routine application of the method ( $n=11$ analytical runs).

\section{Reproducibility of analysis}

Assay performance was also assessed by reproducibility of the analysis $(n=3)$ of randomly selected shrimp samples subjected to various cooking procedures (boiling, frying and grilling) and containing dimetridazole, metronidazole and ronidazole residues, respectively. The precision was in the range of $1.5-16.4 \%$, exceeding $15 \%$ only in one case (Table S3, supplementary data). The EU Commission Decision 2002/657/EC states that 
precision calculated as $\mathrm{CV}$ should be as low as possible and not higher than $23 \%$ for mass fractions over $100 \mu \mathrm{g} \mathrm{kg}^{-1}$. Therefore, the results obtained in this study were well within the guideline and demonstrate high reproducibility of the analysis.

\section{Evaluation of persistence of metronidazole residues in shrimp tissue}

The depletion of DMZ, MNZ and RNZ residues and their hydroxy metabolites (HMMNI and MNZ-OH) were profiled over time as presented in Figure 1. The study served to identify the most suitable nitroimidazole drug marker residues and to investigate the persistence of residues as a function of withdrawal period. In this context residue concentrations at five different time points $(\mathrm{d} 0, \mathrm{~d} 1, \mathrm{~d} 2, \mathrm{~d} 4$ and $\mathrm{d} 8)$ post-treatment were examined in shrimp muscle tissue.

The maximum concentration of nitroimidazole residues measured within the individual shrimp tissue were $361-4189 \mu \mathrm{g} \mathrm{kg}^{-1}, 31509-37780 \mu \mathrm{g} \mathrm{kg}^{-1}$ and $14530-24206$ $\mu \mathrm{kg}^{-1}(n=24)$ in the case of MNZ, DMZ and RNZ, respectively, and occurred on day 0 post-treatment. Residue concentrations rapidly depleted in tissue samples at later time points (Figure 1). However, for at least eight days post-treatment, nitroimidazole residues were detectable in all medicated shrimp tissues. MNZ-OH residues were only detectable on day 0 post-treatment and the concentrations measured were very low in comparison with MNZ level, and ranged $0.28-6.6 \mu \mathrm{gg}^{-1}(n=12)$. Similarly, HMMNI residues were only detectable up to day $1\left(15.0-31.9 \mu \mathrm{g} \mathrm{kg}^{-1}\right)$ or $2\left(2.4 \pm 0.80 \mu \mathrm{g} \mathrm{kg}^{-1}\right)(n=24)$ following DMZ and RNZ treatment, respectively. The CC $\alpha$ of the low residue method were as follows: 0.11 $\mu \mathrm{kg}^{-1}$ (DMZ), $1.0 \mu \mathrm{g} \mathrm{kg}^{-1}$ (HMMNI), $0.07 \mu \mathrm{gg}^{-1}$ (MNZ), $0.13 \mu \mathrm{g} \mathrm{kg}^{-1}$ (MNZ-OH) and 0.33 $\mu \mathrm{g} \mathrm{k}^{-1}$ (RNZ) (Gadaj et al. 2014). It can be concluded that even if nitroimidazole drug level in shrimp tissue is decreasing rapidly in the case of the treatment with DMZ, MNZ and RNZ, 
the parent drugs themselves are the more persistent marker residues and can still be detected after eight days post-medication.

There have been no reports on the persistence of nitroimidazole drug residues in farmed aquaculture species following treatment. Rodriguez et al. (2011) reported on the uptake of MNZ in Artemia (brine shrimp) at different stages of development. Artemia were treated using $50 \mathrm{mg} \mathrm{MNZ}$ per L as an in-water treatment at room temperature $\left(26-28^{\circ} \mathrm{C}\right)$ for $3 \mathrm{~h}$. This study showed that medication levels of $85-143 \mathrm{mg} \mathrm{kg}^{-1}$ incurred in Artemia. The results from the current study showed a lower incursion level of MNZ in shrimp. This fact may be explained by the different capacities of various crustacean species to accumulate metronidazole. Rodriguez et al. (2011) did not report on the depletion of residues over time because samples were collected immediately post-treatment. No further studies have been reported in fish or crustaceans. Polzer et al. (2004) reported on the depletion of nitroimidazole residues in turkey muscle. These studies showed that DMZ and the HMMNI metabolite rapidly depleted in turkey breast meat from $96-2000 \mu \mathrm{g} \mathrm{kg}^{-1}$ (day 0 ) to $<0.8 \mu \mathrm{g} \mathrm{kg}^{-1}$ (day 1 ) and from approximately $1000 \mu \mathrm{gg}^{-1}$ (day 0) to $0.1 \mu \mathrm{g} \mathrm{kg}^{-1}$ (day 3), respectively. MNZ and MNZ-OH residues were also monitored in muscle and liver tissue but were $<1 \mu \mathrm{g} \mathrm{kg}^{-1}$ and not detectable at day 1 .

\section{Stability during cooking}

Since shrimp is usually cooked before consumption and there is also a wide range of readymeals containing shrimp available on the market (Radovnikovic et al. 2013), it is reasonable to assess the stability of drug residues during various cooking conditions. In the current study, the stability of dimetridazole, metronidazole and ronidazole residues in shrimp tissue under frying, grilling, boiling and boiling followed by microwaving was examined. Tissue samples coming from shrimp treated with DMZ, MNZ and RNZ, and containing mainly residues of the parent drug in the case of MNZ and both parent drug and its hydroxy metabolite 
(HMMNI) in the case of $\mathrm{DMZ}$ and RNZ, were used in the study. Changes in nitroimidazole drug and the corresponding hydroxy metabolite residues concentrations for each cooking method are shown in Tables $1-6$. The concentrations detected in raw (uncooked) tissues were adjusted for sample weight changes resulting from the cooking procedures to give concentrations 'expected after cooking'. These expected concentrations were then compared with the concentrations detected after cooking. It should be highlighted that due to the limitations in weight of individual shrimps, only one analysis could be carried out for each raw and cooked sample. Therefore, statistical interpretation of the results is difficult and could only be based on the analytical precision of the method, described in Table S2 and elsewhere (Gadaj et al. 2014). However, repeat analysis was carried out on raw shrimp tissue samples tested during the depletion studies and showed good agreement between results on different days. The method reproducibility was additionally assessed on randomly selected cooked samples as described in detail in the paragraph above.

Small reductions in MNZ concentrations of up to $25 \%$ were evident in the frying and grilling experiments in shrimp tissue samples from the high level treatment group (Table 1). Further frying and grilling studies were carried out using shrimp samples containing MNZ residues in the low range from 0.32 to $12.5 \mu \mathrm{g} \mathrm{kg}^{-1}$. Apparent small increases in MNZ were observed, in two out of three samples following frying. In contrast, grilling the low concentration shrimps showed that MNZ concentrations consistently increased to a greater degree (mean $155 \%$ increase). It should be noted that decreases in water content of samples were monitored during the cooking processes and were factored into residue concentration calculations. It could be postulated that grilling may result in the release of additional tissuebound MNZ residues; however, as increases were not seen in the high concentration samples following cooking, this cannot be claimed with any certainty. 
Additional cooking studies were conducted to investigate the impact of boiling and boiling combined with microwaving on MNZ concentration in shrimp (Table 2). Mean MNZ residues were found to decrease by $42 \%$ and $56 \%$ in the high and low concentration groups after boiling, respectively. Subsequent analysis showed that $36 \%$ and $31 \%$ of MNZ residues in shrimps from the high and low concentration groups were extracted into the water. Following the combined boiling and microwaving treatment, mean MNZ concentrations decreased by $84 \%$ and $89 \%$ in the high and low concentration groups, respectively. Similarly, analysis showed that $34 \%$ and $36 \%$ of MNZ residues from the high and low concentration groups were extracted into the water.

MNZ-OH concentrations were also monitored during the cooking studies but only two samples contained residues and these were reduced marginally following cooking. MNZ-OH does not occur as a major residue in shrimp and does not appear to form during cooking.

In the case of $\mathrm{DMZ}$, the frying experiment showed a small mean reduction of $12 \%$ in shrimp tissue samples from the high level treatment group (Table 3). A similar reduction of $13 \%$ was observed in the high concentration grilling experiment. Further frying and grilling studies were carried out using shrimp samples containing DMZ residues in the low range from 54 to $160 \mu \mathrm{g} \mathrm{kg}^{-1}$. Similar small reductions in DMZ residues were evident in half of the samples, although small apparent increases of up to $11 \%$ were evident in the other half.

Additional cooking studies were conducted to investigate the impact of boiling and boiling combined with microwaving on DMZ concentration in shrimp (Table 4). Mean DMZ residues were found to decrease by $35 \%$ and $54 \%$ in the high and low concentration groups after boiling, respectively. Subsequent analysis showed that $42 \%$ and $40 \%$ of DMZ residues in shrimps from the high and low concentration groups were extracted into the water. Following the combined boiling and microwaving treatment, mean DMZ concentrations decreased by $52 \%$ and $65 \%$ in the high and low concentration groups, respectively. Similarly, 
analysis showed that $45 \%$ and $55 \%$ of $\mathrm{DMZ}$ residues from the high and low concentration groups were extracted into the water.

HMMNI concentrations, following DMZ treatment, were also monitored during the cooking studies but only samples from the high level treatment group contained detectable residues. This showed that frying, grilling, boiling and boiling followed by microwaving reduced mean HMMNI residues in shrimp muscle tissue by $17 \%, 14 \%, 45 \%$ and $44 \%$, respectively. Moreover analysis showed that $40 \%$ of HMMNI residues were extracted into the water in both boiling and boiling followed by microwaving experiment.

In the case of RNZ (Table 5), mean reductions of $7 \%$ and $14 \%$ were observed following frying and grilling of shrimp samples containing high levels of RNZ, respectively. Further frying and grilling studies were carried out using shrimp samples containing RNZ residues in the low range from 2.9 to $15.7 \mu \mathrm{g} \mathrm{kg}^{-1}$. One out of three low range samples showed a large increase in RNZ following frying, whilst grilling resulted in consistent increases (mean 108\%). Additional cooking studies were conducted to investigate the impact of boiling and boiling combined with microwaving on RNZ concentration in shrimp muscle tissue (Table 6). Mean RNZ residues were found to decrease by $43 \%$ and $15 \%$ in the high and low concentration groups after boiling, respectively. Subsequent analysis showed that $49 \%$ and $70 \%$ of RNZ residues from the high and low concentration groups were extracted into the water. Following the combined boiling and microwaving treatment, mean RNZ concentrations decreased by $73 \%$ and $91 \%$ in the high and low concentration groups respectively. Similarly, analysis showed that $43 \%$ and $75 \%$ of RNZ residues from the high and low concentration groups were extracted into the water.

HMMNI concentrations, following RNZ treatment, were also monitored during the cooking studies but only samples from the high level treatment group contained residues. This showed that frying, grilling and boiling followed by microwaving increased mean HMMNI 
residues in the shrimp tissue by $140 \%, 112 \%$ and $920 \%$, respectively, whereas boiling reduced them by $7 \%$. Moreover, analysis showed that HMMNI residues were extracted into the water, to a small but approximately equal degree, in both boiling and boiling followed by microwaving experiment (Table 6). This striking effect of microwaving causing a large increase in HMMNI residues following RNZ treatment (but not DMZ treatment) cannot be easily explained. As suggested previously by Rose et al. (1999), the effect of some conversion from parent drug to its metabolite might occur during various heat processing conditions and superimpose over the other effects. Given that microwaving was applied to single, boiled shrimps with no accompanying liquid or sauce, causing a major loss of water and potentially higher internal temperatures than would be experienced in normal domestic cooking of shrimps in a meal of mixed ingredients, it is possible this increase in HMMNI following microwaving may not be replicated in the kitchen. However, there is a clear pattern across all cooking methods of HMMNI production in shrimps when high levels of RNZ are present. This is unlikely to represent a significant safety issue since HMMNI concentrations derived from RNZ following cooking represent less than $3 \%$ of the accompanying RNZ concentrations across all cooking methods.

A review of the peer reviewed literature showed that no cooking study has been carried out on nitroimidazole drug residues in shrimp or any other aquaculture tissue or food material. Rose et al. (1999) reported on the effect of frying, boiling and microwaving on dimetridazole, ronidazole and HMMNI (metabolite of each drug) residues in egg and chicken muscle. As was also seen in the current study, the analysis of water used for boiling showed that residues of $\mathrm{DMZ}$ and its metabolite were extracted from meat to water. Similarly, the results of frying and microwaving experiments showed reductions in residues concentrations which were accounted for by losses in the juices expressed during cooking. In the case of RNZ, a reduction of residue concentrations was observed following microwaving. 


\section{Conclusions}

The results of the current study demonstrate that dimetridazole, metronidazole and ronidazole are the major residues found in shrimp muscle tissue following an in-water medication. Nitroimidazole hydroxy metabolites were also detected, but only at earlier withdrawal periods. The depletion profiles of the studied drugs show that DMZ and RNZ occur at higher concentrations and are more persistent than MNZ in shrimp following an inwater medication treatment.

The effect of different cooking procedures was investigated and showed that a boilingmicrowaving combination treatment resulted in the greatest reduction of residues in tissue, followed by boiling, then grilling and frying which had similar and less pronounced effects on residue concentrations. There was no clear difference in the stability of the three nitroimidazoles - DMZ was more resilient to the most severe cooking method (boiling and microwaving) than MNZ and RNZ, although DMZ residues in shrimp meat were still degraded by $52-65 \%$. The results indicate that boiling of shrimps prior to further cooking can reduce nitroimidazole exposure, primarily via partial extraction of residues into the water, but will not eliminate residues. Indeed there is the potential that nitroimidazole residues may be converted to more toxic substances following frying, grilling or microwaving. Therefore, cooking cannot be considered as a safeguard against ingestion of harmful nitroimidazole residues.

\section{Acknowledgements}

The research was funded by the Food for Health Research Initiative (FHRI) administered by the Irish Department of Agriculture, Food and Marine and the Health Research Board (Contract 07FHRIAFRC5). We are grateful to Dr. Rungnapa Leelatanawit and Shrimp 
Biotechnology Business Unit, National Centre for Genetic Engineering and Biotechnology (Thailand) for their help with the animal experiment. Our friend and Teagasc colleague $\mathrm{Mr}$ Paddy Byrne (RIP) passed away suddenly during the preparation of this revised manuscript and is acknowledged for analysis of dimetridazole samples included in Table S3. Mr Martin McCormack (Teagasc) is acknowledged for analysing metronidazole and ronidazole samples included in Table S3.

\section{References}

Anon. 1990. Council Regulation no $2377 / 90$ of 26 june 1990 laying down a community procedure for the establishment of maximum residue limits of veterinary medicinal products in foodstuff of animal origin. Off J Eur Comm. L224: 1-136.

Anon. 2007. Community Reference Laboratory guidance paper: 1-8.

Anon. 2010. Commission Regulation (EU) no 37/2010 on pharmacologically active substances and their classification regarding maximum residue limits in foodstuffs of animal origin. Off J Eur Comm. L15: 1-77.

Anon. 2012. The state of world fisheries and aquaculture. Food and Agriculture Organization of the United Nations, Rome, Italy.

Bishop Y 2005. The veterinary formulary. London, Pharmaceutical Press.

Chou HY, Huang CY, Wang CH, Chiang HC, Lo CF. 1995. Pathogenicity of a baculovirus infection causing white spot syndrome in cultured penaeid shrimp in Taiwan. Dis Aquat Organ. 23: 165-173.

Clopton RE, Smith A. 2002. Efficacy of oral sulfadimethoxine against two gregarine parasites, Protomagalhaensia granulosae and Gregarina cubensis (apicomplexa: Eugregarinda), infecting the death's head cockroach, Blaberus discoidalis. J Parasitol. 88: 786-789. 
Cooper KM, Kennedy DG. 2007. Stability studies of the metabolites of nitrofuran antibiotics during storage and cooking. Food Addit Contam. 24: 935-942.

Cooper KM, Whelan M, Danaher M, Kennedy DG. 2011. Stability during cooking of anthelmintic veterinary drug residues in beef. Food Addit Contam: Part A Chem Anal Control Expo Risk Assess. 28: 155-165.

Corliss JP. 1979. Accumulation and depletion of oxytetracycline in juvenile white shrimp (Penaeus setiferus). Aquaculture. 16: 1-6.

Fajer-Ávila EJ, Covarrubias MSM, Abad-Rosales S, Roque A, Meza-Bojórquez P, Hernández-González C. 2005. Effectiveness of oral Elancoban ${ }^{\mathrm{TM}}$ and Avimix-ST ${ }^{\mathrm{TM}}$ against nematopsis (apicomplexa: Porosporidae) gametocyts infecting the shrimp Litopenaeus vannamei. Aquaculture. 244: 11-18.

Gadaj A, di Lullo V, Cantwell H, McCormack M, Furey A, Danaher M. 2014. Determination of nitroimidazole residues in aquaculture tissue using ultra high performance liquid chromatography coupled to tandem mass spectrometry. J Chromatogr B. 960: 105115.

Hose JE, Lightner DV, Redman RM, Danald DA. 1984. Observations on the pathogenesis of the imperfect fungus, Fusarium solani, in the california brown shrimp, Penaeus californiensis. J Invert Pathol. 44: 292-303.

Johnson SK 1995. Handbook of shrimp diseases. TX, Department of Wildlife and Fisheries Sciences Texas A\&M University.

Kaufmann A, Butcher P, Maden K, Walker S, Widmer M. 2011. Development of an improved high resolution mass spectrometry based multi-residue method for veterinary drugs in various food matrices. Anal Chim Acta. 700: 86-94.

Kautsky N, Ronnback P, Tedengren M, Troell M. 2000. Ecosystem perspectives on management of disease in shrimp pond farming. Aquaculture. 191: 145-161.

Lightner DV 1996. A handbook of pathology and diagnostic procedures for diseases of penaeid shrimp. Baton Rouge, LA, U.S.A. 
Mahugo-Santana C, Sosa-Ferrera Z, Torres-Padrón ME, Santana-Rodríguez JJ. 2010. Analytical methodologies for the determination of nitroimidazole residues in biological and environmental liquid samples: A review. Anal Chim Acta. 665: 113122.

Mitrowska K, Posyniak A, Zmudzki J. 2007. The effects of cooking on residues of malachite green and leucomalachite green in carp muscles. Anal Chim Acta. 586: 420-425.

Mitrowska K, Posyniak A, Zmudzki J. 2010. Multiresidue method for the determination of nitroimidazoles and their hydroxy-metabolites in poultry muscle, plasma and egg by isotope dilution liquid chromatography-mass spectrometry. Talanta. 81:1273-1280.

Mottier P, Huré I, Gremaud E, Guy PA. 2006. Analysis of four 5-nitroimidazoles and their corresponding hydroxylated metabolites in egg, processed egg, and chicken meat by isotope dilution liquid chromatography tandem mass spectrometry. J Agric Food Chem. 54: 2018-2026.

Peters RJB, Bolck YJC, Rutgers P, Stolker AAM, Nielen MWF. 2009. Multi-residue screening of veterinary drugs in egg, fish and meat using high-resolution liquid chromatography accurate mass time-of-flight mass spectrometry. J Chromatogr A. 1216: 8206-8216.

Poapolathep A, Poapolathep S, Imsilp K, Wannapat N, Klangkaew N, Kusutjarit N, Kumagai S. 2008. Distribution and residue depletion of oxytetracycline in giant freshwater prawn (Macrobrachium rosenbergii). J Food Protect. 71: 870-873.

Polzer J, Stachel C, Gowik P. 2004. Treatment of turkeys with nitroimidazoles: Impact of the selection of target analytes and matrices on an effective residue control. Anal Chim Acta. 521: 189-200.

Primavera JH 1998. Tropical shrimp farming and its sustainability. London, Academic Press.

Radovnikovic A, Conroy E-R, Gibney M, O'Mahony J, Danaher M. 2013. Residue analyses and exposure assessment of the Irish population to nitrofuran metabolites from different food commodities 2009-2010. Food Addit Contam: Part A Chem Anal Control Expo Risk Assess. 30: 1858-1869. 
Raether W, Hänel H. 2003. Nitrohetrocyclic drugs with broad spectrum activity. Parasitol Res. 90: S19-S39.

Rodriguez L, Livengood EJ, Miles RD, Chapman FA. 2011. Uptake of metronidazole in Artemia at different developmental life stages. J Aquat Anim Health. 23: 100-102.

Rose MD, Bygrave J, Sharman M. 1999. Effect of cooking on veterinary drug residues in food. Part 9. Nitroimidazoles. Analyst. 124: 289-294.

Smith AJ, Clopton RE. 2003. Efficacy of oral metronidazole and potassium sorbate against two gregarine parasites, protomagalhaensia granulosae and Gregarina cubensis (apicomplexa: Eugregarinida), infecting the death's head cockroach, Blaberus discoidalis. Comp Parasitol. 70: 196-199.

Smith S, Gieseker C, Reimschuessel R, Decker CS, Carson MC. 2009. Simultaneous screening and confirmation of multiple classes of drug residues in fish by liquid chromatography-ion trap mass spectrometry. J Chromatogr A. 1216: 8224-8232.

Tojo JL, Santamarina MT. 1998a. Oral pharmacological treatments for parasitic diseases of rainbow trout Oncorhynchus mykiss. I: Hexamita salmonis. Dis Aquat Organ. 33: 5156.

Tojo JL, Santamarina MT. 1998b. Oral pharmacological treatments for parasitic diseases of rainbow trout Oncorhynchus mykiss. III: Ichthyobodo necator. Dis Aquat Organ. 33: 195-199.

Valderrama D, Anderson JL 2011. Shrimp production review. Global Outlook for Aqaculture Leadership 2011, GOAL 2011, Santiago, Chile. 
Figure 1: Depletion profile of $(\mathrm{A})$ dimetridazole, $(\mathrm{B})$ metronidazole and $(\mathrm{C})$ ronidazole in shrimp tissue $(95 \% \mathrm{CL},<\mathrm{i}>\mathrm{n}</ \mathrm{i}>=24$ results per time point).
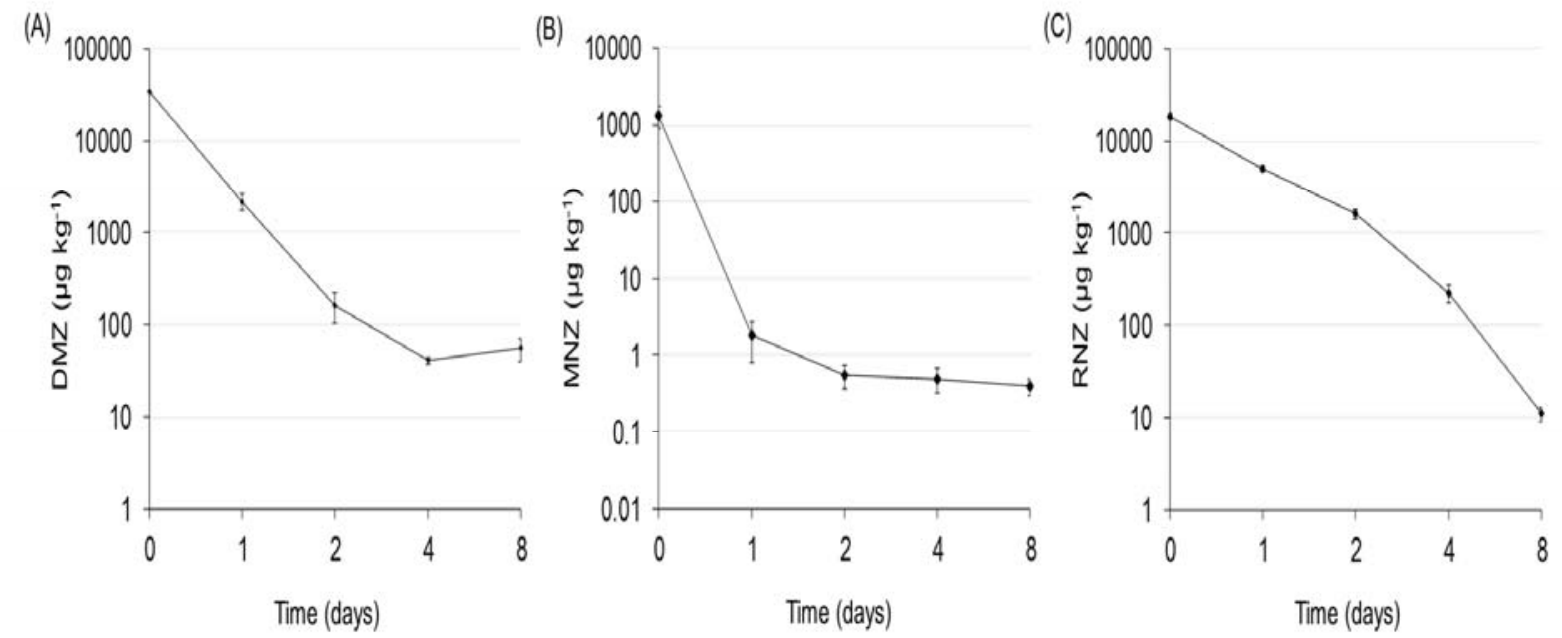
Table 1

Effect of frying and grilling on the concentration of MNZ and MNZ-OH residues in shrimp tissue.

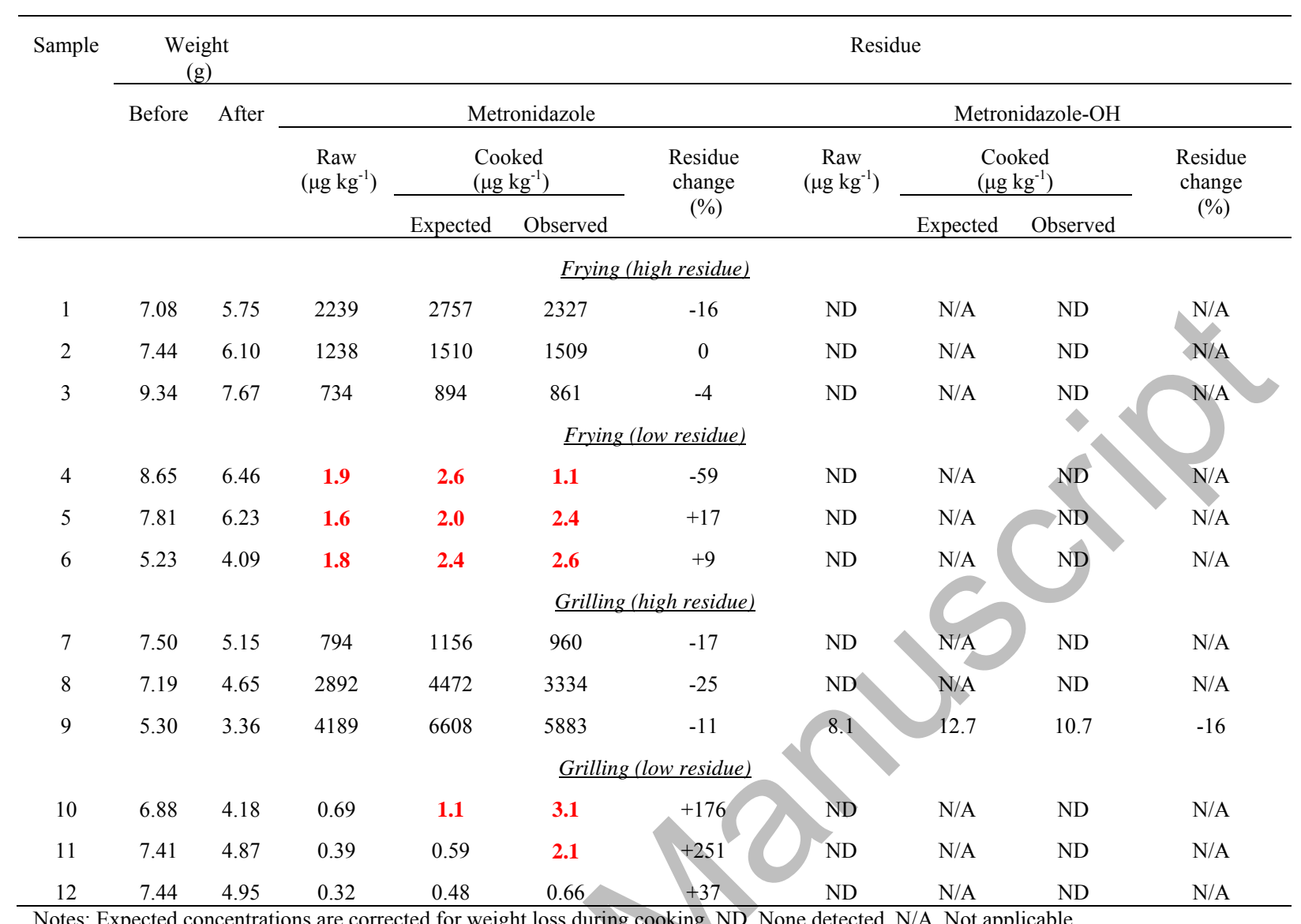

Notes: Expected concentrations are corrected for weight loss during cooking. ND, None detected. N/A, Not applicable. 
Table 2

Effect of boiling and boiling followed by microwaving on the concentration of MNZ and MNZ-OH residues in shrimp tissue.

\begin{tabular}{|c|c|c|c|c|c|c|c|c|c|c|c|}
\hline \multirow[t]{4}{*}{ Sample } & \multicolumn{2}{|c|}{$\begin{array}{l}\text { Weight } \\
\text { (g) }\end{array}$} & \multicolumn{9}{|c|}{ Residue } \\
\hline & \multirow[t]{3}{*}{ Before } & \multirow[t]{3}{*}{ After } & \multicolumn{5}{|c|}{ Metronidazole } & \multicolumn{4}{|c|}{ Metronidazole-OH } \\
\hline & & & \multirow{2}{*}{$\begin{array}{c}\text { Raw } \\
(\mu \mathrm{g} \\
\left.\mathrm{kg}^{-1}\right)\end{array}$} & \multicolumn{2}{|c|}{$\begin{array}{l}\text { Cooked } \\
\left(\mu \mathrm{g} \mathrm{kg}^{-1}\right)\end{array}$} & \multirow[t]{2}{*}{$\begin{array}{l}\text { Water/juices } \\
\quad\left(\mu \mathrm{g} \mathrm{kg}^{-1}\right)\end{array}$} & \multirow{2}{*}{$\begin{array}{c}\text { Residue } \\
\text { change } \\
\text { including } \\
\text { water/juices } \\
(\%)\end{array}$} & \multirow{2}{*}{$\begin{array}{l}\text { Raw } \\
(\mu \mathrm{g} \\
\left.\mathrm{kg}^{-1}\right)\end{array}$} & \multicolumn{2}{|c|}{$\begin{array}{c}\text { Cooked } \\
\left(\mu \mathrm{g} \mathrm{kg}^{-1}\right)\end{array}$} & \multirow{2}{*}{$\begin{array}{c}\text { Residue } \\
\text { change } \\
(\%)\end{array}$} \\
\hline & & & & Expected & Observed & & & & Expected & Observed & \\
\hline \multicolumn{12}{|c|}{ Boiling (high residue) } \\
\hline 13 & 10.95 & 7.46 & 870 & 1277 & 764 & 187 & -9 & ND & $\mathrm{N} / \mathrm{A}$ & ND & A \\
\hline 14 & 6.31 & 4.14 & 1657 & 2526 & 1364 & 256 & -9 & ND & $\mathrm{N} / \mathrm{A}$ & ND & N/A \\
\hline 15 & 9.11 & 6.12 & 830 & 1235 & 750 & 185 & -1 & ND & N/A & & N/A \\
\hline \multicolumn{12}{|c|}{$\underline{\text { Boiling (low residue) }}$} \\
\hline 16 & 5.70 & 3.46 & 1.4 & 2.3 & 0.93 & 0.19 & -25 & ND & $\mathrm{N} / \mathrm{A}$ & ND & $\mathrm{N} / \mathrm{A}$ \\
\hline 17 & 8.82 & 6.21 & 12.5 & 17.7 & 5.5 & 1.2 & -53 & 0.12 & 0.17 & 0.13 & -24 \\
\hline 18 & 7.83 & 5.37 & 4.5 & 6.5 & 4.0 & 0.94 & +3 & ND & & ND & N/A \\
\hline \multicolumn{12}{|c|}{ Boiling followed by microwaving (high residue) } \\
\hline 19 & 9.15 & 1.75 & 717 & 3748 & 353 & 104 & -66 & & $\mathrm{~N} / \mathrm{A}$ & ND & $\mathrm{N} / \mathrm{A}$ \\
\hline 20 & 8.01 & 2.34 & 1245 & 4262 & 1005 & 213 & & ND & N/A & ND & N/A \\
\hline 21 & 8.95 & 1.55 & 931 & 5376 & 852 & 241 & -39 & ND & N/A & ND & N/A \\
\hline \multicolumn{12}{|c|}{ Boiling followed by microwaving (low residue) } \\
\hline 22 & 8.47 & 1.42 & 1.8 & 10.9 & 0.96 & 0.31 & -58 & ND & $\mathrm{N} / \mathrm{A}$ & ND & $\mathrm{N} / \mathrm{A}$ \\
\hline 23 & 8.48 & 1.84 & 0.66 & 3.0 & 0.39 & 0.13 & -52 & ND & N/A & ND & N/A \\
\hline 24 & 11.29 & 1.93 & 1.4 & 8.4 & 0.97 & 0.40 & -49 & ND & N/A & ND & N/A \\
\hline
\end{tabular}

Notes: Expected concentrations are corrected for weight loss during cooking. ND, None detected. N/A, Not applicable. 
Table 3

Effect of frying and grilling on the concentration of DMZ and HMMNI residues in shrimp tissue.

\begin{tabular}{|c|c|c|c|c|c|c|c|c|c|c|}
\hline \multirow[t]{4}{*}{ Sample } & \multicolumn{2}{|c|}{$\begin{array}{c}\text { Weight } \\
(\mathrm{g})\end{array}$} & \multicolumn{7}{|c|}{ Residue } & \\
\hline & \multirow[t]{3}{*}{ Before } & \multirow[t]{3}{*}{ After } & \multicolumn{4}{|c|}{ Dimetridazole } & \multicolumn{4}{|c|}{ HMMNI } \\
\hline & & & \multirow[t]{2}{*}{$\begin{array}{c}\mathrm{Raw} \\
\left(\mu \mathrm{g} \mathrm{kg}^{-1}\right)\end{array}$} & \multicolumn{2}{|c|}{$\begin{array}{c}\text { Cooked } \\
\left(\mu \mathrm{g} \mathrm{kg}^{-1}\right)\end{array}$} & \multirow{2}{*}{$\begin{array}{c}\text { Residue } \\
\text { change } \\
(\%)\end{array}$} & \multirow[t]{2}{*}{$\begin{array}{c}\text { Raw } \\
\left(\mu \mathrm{g} \mathrm{kg}^{-1}\right)\end{array}$} & \multicolumn{2}{|c|}{$\begin{array}{c}\text { Cooked } \\
\left(\mu \mathrm{g} \mathrm{kg}^{-1}\right)\end{array}$} & \multirow{2}{*}{$\begin{array}{c}\text { Residue } \\
\text { change } \\
(\%)\end{array}$} \\
\hline & & & & Expected & Observed & & & Expected & Observed & \\
\hline \multicolumn{11}{|c|}{ Frying (high residue) } \\
\hline 25 & 7.73 & 6.22 & 34668 & 43085 & 38907 & -10 & 21.9 & 27.2 & 23.8 & -13 \\
\hline 26 & 5.44 & 4.42 & 36054 & 44374 & 40451 & -9 & 23.0 & 28.3 & 21.6 & \\
\hline 27 & 7.50 & 5.81 & 37780 & 48769 & 40349 & -17 & 21.0 & 27.1 & 23.1 & \\
\hline \multicolumn{11}{|c|}{ Frying (low residue) } \\
\hline 28 & 5.36 & 3.90 & 83 & 114 & 101 & -12 & ND & N/A & & N/A \\
\hline 29 & 7.62 & 5.83 & 54 & 70 & 78 & +11 & ND & N/A & & N/A \\
\hline 30 & 5.47 & 3.92 & 54 & 75 & 78 & +3 & ND & N/A & ND & N/A \\
\hline \multicolumn{11}{|c|}{ Grilling (high residue) } \\
\hline 31 & 8.16 & 4.90 & 32323 & 53827 & 44958 & -16 & 32.2 & & 40.4 & -25 \\
\hline 32 & 11.82 & 8.23 & 33509 & 48126 & 47766 & -1 & & 56 & 61 & 8 \\
\hline 33 & 6.50 & 3.60 & 33239 & 60015 & 46875 & -22 & & 61 & 45.7 & -25 \\
\hline 34 & 8.70 & 5.96 & 160 & 233 & 249 & & ND & N/A & ND & N/A \\
\hline 35 & 7.39 & 5.08 & 95 & 139 & 111 & & ND & N/A & ND & N/A \\
\hline 36 & 11.59 & 8.00 & 110 & 159 & 136 & -15 & ND & N/A & ND & N/A \\
\hline
\end{tabular}


Table 4

Effect of boiling and boiling followed by microwaving on the concentration of DMZ and HMMNI residues in shrimp tissue.

\begin{tabular}{|c|c|c|c|c|c|c|c|c|c|c|c|c|}
\hline \multirow[t]{4}{*}{$\begin{array}{c}\text { Sampl } \\
\text { e }\end{array}$} & \multicolumn{2}{|c|}{$\begin{array}{l}\text { Weight } \\
\text { (g) }\end{array}$} & \multicolumn{10}{|c|}{ Residue } \\
\hline & \multirow{3}{*}{$\begin{array}{l}\text { Befor } \\
\text { e }\end{array}$} & \multirow{3}{*}{$\begin{array}{c}\text { Afte } \\
r\end{array}$} & \multicolumn{5}{|c|}{ Dimetridazole } & \multicolumn{5}{|c|}{ HMMNI } \\
\hline & & & \multirow{2}{*}{$\begin{array}{l}\text { Raw } \\
(\mu \mathrm{g} \\
\left.\mathrm{kg}^{-1}\right)\end{array}$} & \multicolumn{2}{|c|}{$\begin{array}{c}\text { Cooked } \\
\left(\mu \mathrm{g} \mathrm{kg}^{-1}\right)\end{array}$} & \multirow{2}{*}{$\begin{array}{c}\text { Water/juic } \\
\text { es } \\
\left(\mu \mathrm{g} \mathrm{kg}^{-1}\right)\end{array}$} & \multirow{2}{*}{$\begin{array}{c}\text { Residue } \\
\text { change } \\
\text { including } \\
\text { water/juic } \\
\text { es } \\
(\%)\end{array}$} & \multirow{2}{*}{$\begin{array}{c}\mathrm{Ra} \\
\mathrm{W} \\
(\mu \mathrm{g} \\
\mathrm{kg}^{-} \\
\left.{ }^{1}\right)\end{array}$} & \multicolumn{2}{|c|}{$\begin{array}{l}\text { Cooked } \\
\left(\mu \mathrm{g} \mathrm{kg}^{-1}\right)\end{array}$} & \multirow{2}{*}{$\begin{array}{c}\text { Water/juic } \\
\text { es } \\
\left(\mu \mathrm{g} \mathrm{kg}^{-1}\right)\end{array}$} & \multirow{2}{*}{$\begin{array}{c}\text { Residue } \\
\text { change } \\
\text { including } \\
\text { water/juic } \\
\text { es } \\
(\%)\end{array}$} \\
\hline & & & & $\begin{array}{c}\text { Expect } \\
\text { ed }\end{array}$ & $\begin{array}{c}\text { Observ } \\
\text { ed }\end{array}$ & & & & $\begin{array}{c}\text { Expect } \\
\text { ed }\end{array}$ & $\begin{array}{l}\text { Observ } \\
\text { ed }\end{array}$ & & \\
\hline \multicolumn{13}{|c|}{ Boiling (high residue) } \\
\hline 37 & 6.24 & 3.58 & $\begin{array}{c}3448 \\
4\end{array}$ & 60107 & 32331 & 7780 & +5 & $\begin{array}{c}11 . \\
3\end{array}$ & 19.7 & 8.6 & 2.3 & \\
\hline 38 & 8.03 & 5.41 & $\begin{array}{c}3214 \\
0\end{array}$ & 47704 & 34177 & 7422 & +13 & $\begin{array}{c}19 . \\
5\end{array}$ & 28.9 & 16.8 & & \\
\hline 39 & 10.11 & 7.19 & $\begin{array}{c}3332 \\
8\end{array}$ & 46862 & 31978 & 6998 & +4 & $\begin{array}{c}25 . \\
3\end{array}$ & 35.6 & 22.4 & 5.1 & \\
\hline \multicolumn{13}{|c|}{$\underline{\text { Boiling (low residue) }}$} \\
\hline 40 & 7.76 & 5.15 & 118 & 178 & 92 & 18.6 & -19 & ND & N/A & ND & ND & N/A \\
\hline 41 & 7.02 & 4.40 & 57 & 91 & 48.2 & 11.8 & -2 & ND & & ND & ND & N/A \\
\hline 42 & 5.60 & 3.10 & 77 & 139 & 44.6 & 15.3 & -20 & ND & N/A & ND & ND & N/A \\
\hline \multicolumn{13}{|c|}{ Boiling followed by microwaving (high residue) } \\
\hline 43 & 7.33 & 2.28 & $\begin{array}{c}3365 \\
9\end{array}$ & 108210 & 49198 & 6694 & & & 112 & 62 & 6.9 & -1 \\
\hline 44 & 7.01 & 1.94 & $\begin{array}{c}3443 \\
4\end{array}$ & 124424 & 58567 & 7023 & & & 118 & 67 & 6.2 & -2 \\
\hline 45 & 7.12 & 2.14 & $\begin{array}{c}3150 \\
9\end{array}$ & 104834 & 54102 & & & 88 & 293 & 167 & 14.0 & -8 \\
\hline \multicolumn{13}{|c|}{ Boiling followed by microwaving (low residue) } \\
\hline 46 & 6.74 & 2.28 & 85 & 252 & 96 & 25.3 & +6 & ND & N/A & ND & ND & N/A \\
\hline 47 & 10.76 & 2.61 & 91 & 375 & 144 & 25.2 & -16 & ND & N/A & ND & ND & N/A \\
\hline 48 & 7.55 & 1.58 & 69 & 330 & 99 & 16.2 & -19 & ND & N/A & ND & ND & $\mathrm{N} / \mathrm{A}$ \\
\hline
\end{tabular}

Notes: Expected concentrations are corrected for weight loss during cooking. ND, None detected. N/A, Not applicable. 
Table 5

Effect of frying and grilling on the concentration of RNZ and HMMNI residues in shrimp tissue.

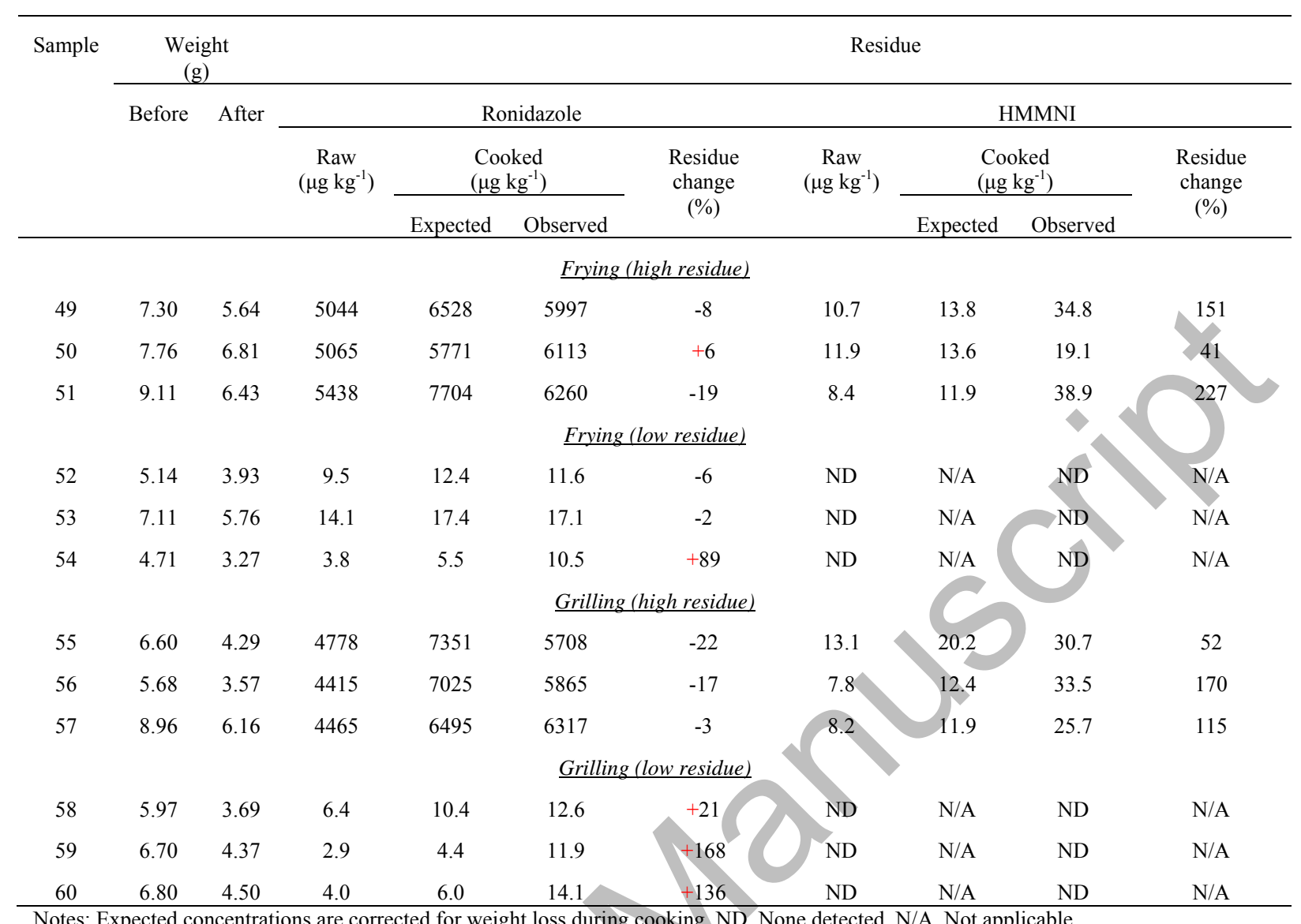

Notes: Expected concentrations are corrected for weight loss during cooking. ND, None detected. N/A, Not applicable. 
Table 6

Effect of boiling and boiling followed by microwaving on the concentration of RNZ and HMMNI residues in shrimp tissue.

\begin{tabular}{|c|c|c|c|c|c|c|c|c|c|c|c|c|}
\hline \multirow[t]{4}{*}{$\begin{array}{l}\text { Sampl } \\
\mathrm{e}\end{array}$} & \multicolumn{2}{|c|}{$\begin{array}{l}\text { Weight } \\
(\mathrm{g})\end{array}$} & \multicolumn{10}{|c|}{ Residue } \\
\hline & \multirow{3}{*}{$\begin{array}{c}\text { Befor } \\
\text { e }\end{array}$} & \multirow{3}{*}{$\begin{array}{l}\text { Afte } \\
\mathrm{r}\end{array}$} & \multicolumn{5}{|c|}{ Ronidazole } & \multicolumn{5}{|c|}{ HMMNI } \\
\hline & & & \multirow{2}{*}{$\begin{array}{l}\mathrm{Ra} \\
\mathrm{W} \\
(\mu \mathrm{g} \\
\mathrm{kg}^{-} \\
\left.{ }^{1}\right)\end{array}$} & \multicolumn{2}{|c|}{$\begin{array}{c}\text { Cooked } \\
\left(\mu \mathrm{g} \mathrm{kg}^{-1}\right)\end{array}$} & \multirow{2}{*}{$\begin{array}{c}\text { Water/juic } \\
\text { es } \\
\left(\mu \mathrm{g} \mathrm{kg}^{-1}\right)\end{array}$} & \multirow{2}{*}{$\begin{array}{c}\text { Residue } \\
\text { change } \\
\text { including } \\
\text { water/juic } \\
\text { es } \\
(\%)\end{array}$} & \multirow{2}{*}{$\begin{array}{l}\mathrm{Ra} \\
\mathrm{W} \\
(\mu \mathrm{g} \\
\mathrm{kg}^{-} \\
\left.{ }^{1}\right)\end{array}$} & \multicolumn{2}{|c|}{$\begin{array}{c}\text { Cooked } \\
\left(\mu \mathrm{g} \mathrm{kg}^{-1}\right)\end{array}$} & \multirow{2}{*}{$\begin{array}{c}\text { Water/juic } \\
\text { es } \\
\left(\mu \mathrm{g} \mathrm{kg}^{-1}\right)\end{array}$} & \multirow{2}{*}{$\begin{array}{c}\text { Residue } \\
\text { change } \\
\text { including } \\
\text { water/juic } \\
\text { es } \\
(\%)\end{array}$} \\
\hline & & & & $\begin{array}{c}\text { Expecte } \\
\text { d }\end{array}$ & $\begin{array}{c}\text { Observe } \\
\mathrm{d}\end{array}$ & & & & $\begin{array}{c}\text { Expecte } \\
\mathrm{d}\end{array}$ & $\begin{array}{c}\text { Observe } \\
\mathrm{d}\end{array}$ & & \\
\hline \multicolumn{13}{|c|}{$\underline{\text { Boiling (high residue) }}$} \\
\hline 61 & 8.85 & 5.74 & $\begin{array}{c}437 \\
3\end{array}$ & 6743 & 4030 & 998 & +5 & 7.1 & 10.9 & 14.8 & 4.9 & \\
\hline 62 & 7.95 & 4.58 & $\begin{array}{c}464 \\
5\end{array}$ & 8063 & 4321 & 1038 & +4 & $\begin{array}{c}14 . \\
1\end{array}$ & 24.5 & 18.0 & & 68 \\
\hline 63 & 6.40 & 3.65 & $\begin{array}{c}450 \\
9\end{array}$ & 7905 & 4392 & 872 & +8 & $\begin{array}{c}12 . \\
4\end{array}$ & 21.7 & & 4.0 & 57 \\
\hline \multicolumn{13}{|c|}{$\underline{\text { Boiling (low residue) }}$} \\
\hline 64 & 6.85 & 4.30 & $\begin{array}{c}13 . \\
2\end{array}$ & 21.0 & 13.5 & 3.7 & +42 & ND & & & ND & N/A \\
\hline 65 & 8.63 & 6.07 & 9.2 & 13.1 & 12.5 & 3.5 & +66 & ND & J/A & ND & ND & N/A \\
\hline 66 & 9.28 & 6.23 & $\begin{array}{c}14 . \\
2\end{array}$ & 21.2 & 20.5 & 4.1 & +56 & & & ND & ND & N/A \\
\hline \multicolumn{13}{|c|}{ Boiling followed by microwaving (high residue) } \\
\hline 67 & 9.64 & 2.13 & $\begin{array}{c}575 \\
8\end{array}$ & 26059 & 6102 & 1301 & & & 52 & 738 & 7.7 & 1442 \\
\hline 68 & 6.89 & 1.71 & $\begin{array}{c}489 \\
5\end{array}$ & 19725 & 8868 & & & $\begin{array}{c}12 . \\
9\end{array}$ & 52 & 393 & 4.6 & 743 \\
\hline 69 & 9.31 & 1.79 & $\begin{array}{c}364 \\
6\end{array}$ & 18962 & 2508 & 968 & -38 & 9.9 & 51 & 450 & 5.0 & 865 \\
\hline \multicolumn{13}{|c|}{ Boiling followed by microwaving (low residue) } \\
\hline 70 & 6.60 & 1.22 & $\begin{array}{c}15 . \\
7\end{array}$ & 85 & & & -13 & ND & $\mathrm{N} / \mathrm{A}$ & ND & ND & N/A \\
\hline 71 & 6.26 & 1.19 & 8.6 & 45.0 & 1.3 & 4.0 & +26 & ND & N/A & ND & ND & N/A \\
\hline 72 & 6.20 & 1.06 & 5.8 & 34.2 & 3.8 & 2.8 & +36 & ND & N/A & ND & ND & N/A \\
\hline
\end{tabular}




\section{Table S1}

UHPLC-MS/MS conditions.

\begin{tabular}{|c|c|c|c|c|c|c|}
\hline Analyte & $\begin{array}{c}\mathrm{T}_{\mathrm{R}}^{\mathrm{a}} \\
(\min )\end{array}$ & $\begin{array}{l}\text { Transition } \\
(\mathrm{m} / \mathrm{z})\end{array}$ & $\begin{array}{l}\text { Dwell } \\
\text { time } \\
\text { (s) }\end{array}$ & $\begin{array}{l}\text { Cone } \\
\text { (V) }\end{array}$ & $\begin{array}{l}\mathrm{CE}^{\mathrm{b}} \\
(\mathrm{eV})\end{array}$ & IS $^{\mathrm{c}}$ \\
\hline $\mathrm{DMZ}$ & 2.67 & $\begin{array}{l}141.9 \rightarrow 96.0^{\mathrm{d}} \\
141.9 \rightarrow 81.0\end{array}$ & 0.075 & 23 & $\begin{array}{l}15 \\
22\end{array}$ & \\
\hline $\mathrm{DMZ}^{-\mathrm{D}_{3}}$ & 2.64 & $144.9 \rightarrow 99.0$ & 0.075 & 25 & 15 & IS \\
\hline HMMNI & 1.81 & $\begin{array}{l}157.9 \rightarrow 139.9^{\mathrm{d}} \\
157.9 \rightarrow 55.1\end{array}$ & & & $\begin{array}{l}12 \\
17\end{array}$ & $\mathrm{HMMNI}-\mathrm{D}_{3}$ \\
\hline $\mathrm{HMMNI}^{-\mathrm{D}_{3}}$ & 1.79 & $160.9 \rightarrow 142.9$ & 0.020 & 20 & 12 & IS \\
\hline MNZ-OH & 1.46 & $\begin{array}{l}187.9 \rightarrow 123.0^{\mathrm{d}} \\
187.9 \rightarrow 126.0\end{array}$ & 0.100 & 21 & $\begin{array}{l}12 \\
16\end{array}$ & MNZ-OH-D 2 \\
\hline $\mathrm{MNZ}-\mathrm{OH}-\mathrm{D}_{2}$ & 1.46 & $189.9 \rightarrow 128.0$ & 0.100 & 21 & 17 & IS \\
\hline MNZ & & $172.0 \rightarrow 128.0^{\mathrm{d}}$ & 0.040 & 20 & 14 & MNZ- $13 \mathrm{C}_{2}, 15 \mathrm{~N}_{2}$ \\
\hline & & $172.0 \rightarrow 82.0$ & & & 23 & \\
\hline$M N Z-13 C_{2}, 15 N_{2}$ & 2.17 & $176.0 \rightarrow 132.0$ & 0.040 & 21 & 14 & IS \\
\hline RNZ & 2.14 & $200.9 \rightarrow 139.9^{\mathrm{d}}$ & 0.040 & 16 & 11 & RNZ-D3 \\
\hline & & $200.9 \rightarrow 55.0$ & & & 20 & \\
\hline RNZ-D3 & 2.12 & $203.9 \rightarrow 142.9$ & 0.040 & 16 & 11 & IS \\
\hline
\end{tabular}


Table S2

Intra- and inter-assay validation data.

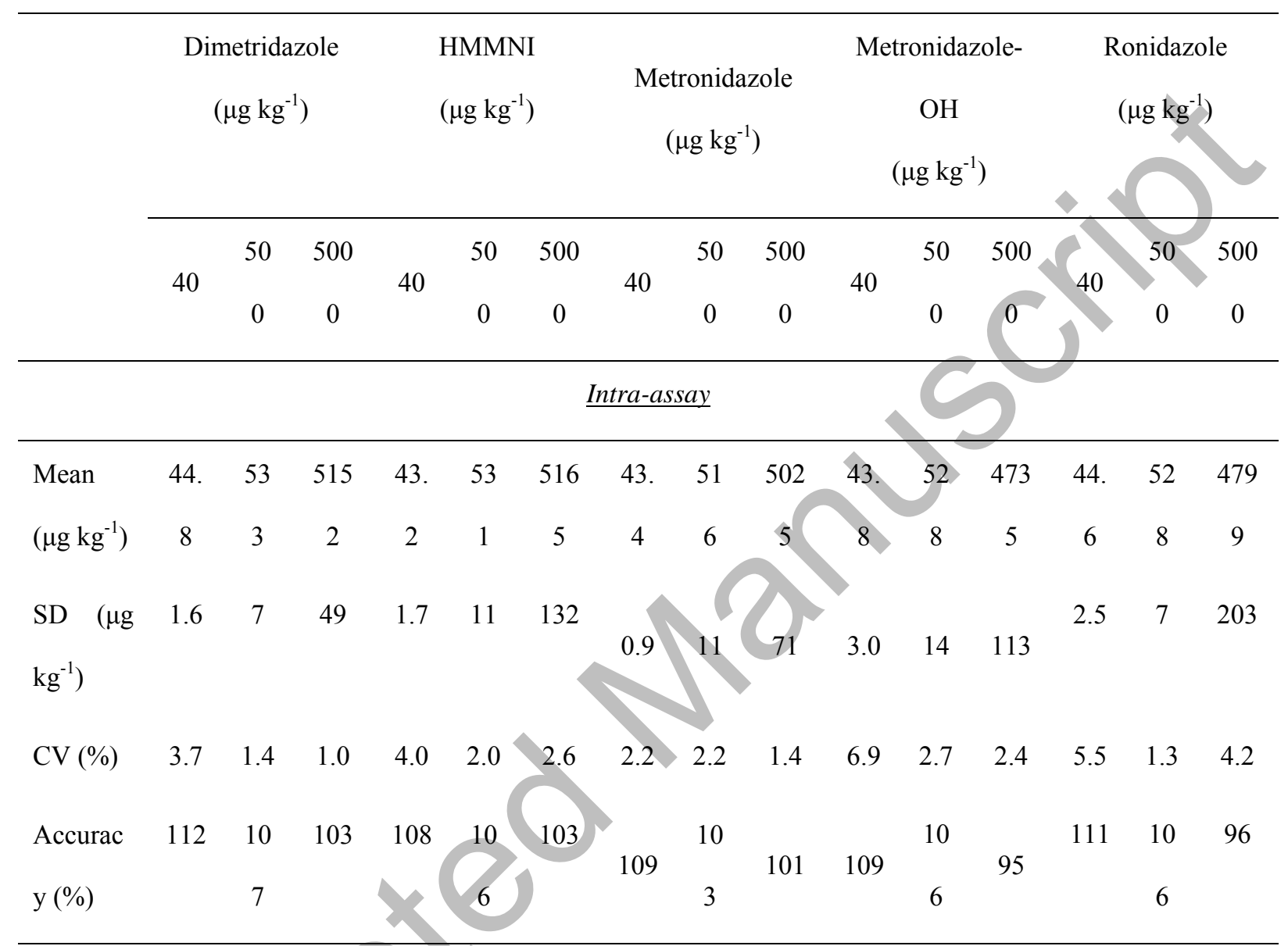

\section{$\underline{\text { Inter-assay }}$}

\begin{tabular}{|c|c|c|c|c|c|c|c|c|c|c|c|c|c|c|c|}
\hline Mean & 44. & 53 & 503 & 43. & 52 & 510 & 43. & 51 & 501 & 45. & 52 & 475 & 45. & 52 & 482 \\
\hline$\left(\mu \mathrm{g} \mathrm{kg}^{-1}\right)$ & 5 & 0 & 9 & 5 & 5 & 2 & 1 & 7 & 9 & 7 & 9 & 8 & 0 & 9 & 6 \\
\hline & 2.1 & 17 & 113 & 5.4 & 17 & 189 & 3.0 & 12 & 103 & 4.3 & 11 & 102 & 3.0 & 9 & 153 \\
\hline CV (\%) & 4.7 & 3.3 & 2.2 & $\begin{array}{c}12 . \\
4\end{array}$ & 3.2 & 3.7 & 6.9 & 2.3 & 2.1 & 9.3 & 2.0 & 2.2 & 6.7 & 1.8 & 3.2 \\
\hline $\begin{array}{l}\text { Accurac } \\
\text { y }(\%)\end{array}$ & 111 & 10 & 101 & 109 & 10 & 102 & 108 & $\begin{array}{c}10 \\
3\end{array}$ & 100 & 114 & $\begin{array}{l}10 \\
6\end{array}$ & 95 & 113 & $\begin{array}{l}10 \\
6\end{array}$ & 97 \\
\hline
\end{tabular}




\section{Table S3}

Method reproducibility results for cooked shrimp samples $(n=3)$.

\begin{tabular}{|c|c|c|c|c|}
\hline Sample & Analyte & Sample treatment & $\begin{array}{c}\text { Mean } \pm \text { SD } \\
\left(\mu \mathrm{kg}^{-1}\right)\end{array}$ & $\begin{array}{l}\mathrm{CV} \\
(\%)\end{array}$ \\
\hline 1 & Dimetridazole & Boiling & $47.8 \pm 0.7$ & \\
\hline 2 & & Frying & $130 \pm 5.0$ & 3.9 \\
\hline 3 & & Grilling & $123 \pm 8.0$ & 6.7 \\
\hline 4 & Metronidazole & Boiling & & 4.2 \\
\hline 5 & & Fry & $1.3 \pm 0.1$ & 8.9 \\
\hline 6 & & ing & $2.1 \pm 0.1$ & 5.9 \\
\hline 7 & Ronidazole & .1 & $16.9 \pm 0.6$ & 3.4 \\
\hline 8 & & Frying & $22.9 \pm 0.7$ & 3.1 \\
\hline 9 & & Grilling & $23.3 \pm 3.8$ & 16.4 \\
\hline
\end{tabular}

